\title{
GOVERNMENT LEGAL ACT COMPARISON BETWEEN INDONESIA AND SOUTH KOREA IN HANDLING COVID-19 PANDEMIC
}

\author{
Isma Novalia Firdha Susanto ${ }^{\text {, Bayu Aji Satria² }}{ }^{\text {, Sholahuddin Al-Fatih }}{ }^{3^{*}}$ \\ 1,2,3 Faculty of Law, University of Muhammadiyah Malang, \\ * Correspondence email: sholahuddin.alfath@gmail.com
}

\begin{abstract}
Coronavirus Disease of 2019 (COVID-19) with the official name of SARS-CoV-2 has been a serious emerging alert for countries around the world, which makes it a global outbreak of respiratory illness caused by a novel (new) coronavirus. Some countries did a remarkable job on flatten their COVID-19 case rate curve, the finest world reputation in handling this pandemic is given to the Republic of Korea or more known as South Korea which has amazed other world leaders wondering how Moon Jae-in, current President of South Korea, has successfully implied effective and accurate strategies in handling this world outbreak in South Korea. Asides from South Korea succeed, there are some countries who are fall way behind such as the Republic of Indonesia who is currently concerning not only in the medical sector, but the emerging economic sector is severely impacted which leaves us a solicitous feeling towards the future of our nation. In this case, a comparative study is needed to reflect on what has not yet done right. This paper discusses what sort of precise policy reconstructions should be adapted by the Indonesian government from the South Korean government's effective strategy accuracy in handling COVID-19. The harmony between effective regulations implemented by South Korean government and its people's social responsibility should be taken seriously as an example to adapt by both Indonesian government and Indonesian citizens.
\end{abstract}

KEYWORDS: COVID-19; Government Act; Legal Policy

\section{INTRODUCTION}

Contagious COVID-19 has been a bizarre concern for the world, including in Indonesia. This virus is categorized as a new virus which known as a novel virus. This virus was originated from Wuhan, China, which was first reported in December 2019 (RA, Hamdika, \& Al-Fatih, 2020). The government of China emerged a citywide lockdown in Wuhan for three months and officially ended on April 8. That news caused the citywide lockdown only lasted for 76 days.

After that, there was a group of new COVID-19 new infection cases reported by the media on Monday, May 11 2020. This news spread all over the world so rapidly later (AlFatih, Ahsany, \& Alamsyah, 2020). A lot of countries worldwide are currently facing an emerging hard phase of COVID-19. Earlier, Italy was breaking the world news due to bizarre number of emerging cases they're facing, which then replaced by The United States of 
America which now sitting on the first place of the most severe COVID-19 cases emergency in the world with the highest number of positive cases reported leading by 1,408,636 positive cases, 83,425 deaths, and 296,746 recovered cases by May 132020 ("Worldometer," 2020).

Asides from those ironic updates mentioned above, there is one country that has been one out standing role model in the world. This country is South Korea. The overall of reported new cases graphic in South Korea has slowed down dramatically from 909 new cases recorded on February 29 2020, down to 74 cases on March 162020 (Hopkins Tanne et al., 2020). The latest report on COVID-19 in South Korea as shown on their Ministry of Health and Welfare website by May 132020 is accumulated confirmed cases of 10,962, with 9,695 patients released from isolation, a 1,008 are still on isolation, and 259 total number of deceased ("Coronavirus Disease-19(COVID-19), Republic of Korea," 2020).

Although the total confirmed seems much higher compared to their reputable slowdown last February, Republic of Korea can maintain the stability of their positivity rate that only hit the total rate of 1.6\% ("Coronavirus Disease-19(COVID-19), Republic of Korea," 2020). This remarkable achievement done by their government is proven by how the citizens of South Korea can still on their casual daily move for groceries, dine in at restaurants, gaming, even just for a casual stroll through the city.

Based on data given above, the objective of this research is the comparison of effective and accurate policies regulated by the governments of South Korea and Indonesia. This comparative study aims to comprehend the effectiveness and accurate policies regulated by the government act in Indonesia this far to monitor what policies should be emulated by the government of Indonesia based on strategic policies that have been successfully implemented by the government of South Korea.

Indonesia who is currently lagging behind other countries in handling COVID-19 outbreak crisis is certainly concerning for the citizens themselves. Not only relying on policies ordered by the government, the lack of awareness among the citizens is also a huge issue in handling this pandemic. People's self-interest behaviour has not been helpful on lowering the curve at all. Asides from the fact that unidentified invisible carriers who do not show any symptoms are noxious to vulnerable infected people with health problems (Abdillah, 2020), the people themselves oftentimes fail to obey the urgency of physical distancing itself (Pratama \& Hidayat, 2020). This case happened on the official closing of McDonald's Sarinah on May 102020 in Central Jakarta, where a huge mass gathered at the location to protest against its closing regulation.

The aim of this research is to denote how serious government acts (comparative study in South Korea and Indonesia) could impact the effectiveness accuracy of what policies should be implied in order to flatten the COVID-19 case rate graphic. Therefore, the formulation of problems that will be excavated in this research are: (1) What successful strategies are implied by the government of South Korea in handling the emerging COVID19 pandemic in South Korea; and (2) How well the accuracy of current COVID-19 government acts implied by the government of Indonesia in Indonesia is; and (3) What sort of precise policy reconstructions should be adapted by the Indonesian government from the South Korean government's effective strategy in handling COVID-19.

\section{RESEARCH METHODS}


The method used in this research article is the normative juridical method, which conducted by examining the rules relating to the problem to be discussed, as well as examining the norms (Peter Mahmud Marzuki, 2014). Moreover, there are three approaches used in this study, which are the statute approach, comparative approach and conceptual approach.

The first approach, which is the statute approach. The regulations uses in this research such as: 1) Law No. 6 of 2018; 2) Government Regulation No. 21 of 2020; 3) Minister of Health Regulation No. 9 of 2020; 4) Government Regulation in Lieu of Law No. 1 of 2020; and 5) the Minister of Villages and Development of Underdeveloped Regions and Transmigration Regulation No. 6 of 2020.

The conceptual approach moves from the views and doctrines that have developed in the science of law. Moreover, the conceptual approach refers to the concepts about common terms, public property, trademark registration, and trademark cancellation. This concept can be found in scientific literature, scholarly opinions, and legal doctrines (Peter Mahmud Marzuki, 2014). Furthermore, the legal sources used in this study are the primary legal sources, such as: 1) Law No. 6 of 2018; 2) Government Regulation No. 21 of 2020; 3) Minister of Health Regulation No. 9 of 2020; 4) Government Regulation in Lieu of Law No. 1 of 2020; and 5) the Minister of Villages and Development of Underdeveloped Regions and Transmigration Regulation No. 6 of 2020. Secondary data includes legal provision documents, journals, scientific articles, books, dictionaries, as well as the encyclopaedia as tertiary legal sources.

\section{RESULT AND DISCUSSION}

The outbreak of COVID-19 has been causing chaotic situations for governments around the world. They are faced with the urgency where they must make difficult policy decisions to mitigate this outbreak, including by rapidly mobilizing these policy decisions to minimize COVID-19 transmission. This global outbreak has significantly affected severe negative impacts throughout the world. Those impacts are shocks to labour supply, shocks to economic sector, shocks to the cost of production (such as trade and transportation), shocks to consumption demands, shocks to government expenditure, etc. The Republic of Indonesia is currently facing its critical phase where everything seems to be likely not under control. Where is the actual problem located at? Therefore, we need to analyse on how other countries, like South Korea, which have successfully transmitting the expansion of this global outbreak.

\section{Perceptive Clever Strategies Implied by South Korean Government in Handling COVID-19 Outbreaks}

The Republic of Korea which is more known as South Korea has written one of the most successful report in flattening the curve which made them a role model for other countries dealing with the same novel virus outbreak. Their key tactics of this success are data transparency and massive well-organized rapid testing program which have slowed down the infection of COVID-19 (Valerisha \& Putra, 2020). By March 16, more than 270,000 citizens had tested with the massive testing program (Cohen \& Kupferschmidt, 2020). Conducting mass rapid testing has proven as an effective strategy to prevent the expansion 
of COVID-19 infections, both carried out for those who seem to be infected and not, so that the positive patients can be isolated as soon as possible. South Korea carried a mass rapid test known as Reverse Transcription Polymerase Chain Reaction (RT-PCR) to diagnose COVID-19 using swab test kits given for free.

The free massive testing program conducted by the government of South Korea shows how serious they care about the safety of their citizens more than how much money they need to spend to conduct the program. Despites, their intention has protected their economy sector from massive shocks. As we know that the economic sector is the most severely impacted area from this world outbreak. With this smart action, the spread of the COVID-19 infection can be sturdily prevented and the curve can be flattened rapidly. In consequence, the wealth of their citizens can be protected as well. Massive unemployment, business bankruptcy, and worsen poverty scenarios are unlikely to happen. Even if there will be some possibilities any of those scenarios may happen in the future prediction, if the outbreak still continues, the probability is really slight.

South Korea faced uncontrolled outbreaks in Daegu area with hundreds of new infected patients per day starting from mid-February (Her, 2020). The Government of South Korea immediately called for urgent meeting for internal government members and the medical experts as soon as they discovered their first case of COVID-19. They responded to every detail with serious professional actions, which led them to an effective mitigation strategy. The RT-PCR screening has several aims, which are to identify patients with immediate response early to prevent the expansion of the virus to a larger scope of the community, and the other one to avoid the shutdown of unaffected hospitals in order to further infection explosion possibility. Those action and response according to Art 76 of the Constitution of South Korea Republic (Lee \& Kim, 2021).

The immediate actions taken by South Korean government is a really great example to be implemented by the governments in other countries worldwide, including the Republic of Indonesian government. Immediate and serious actions in accordance of responding to an outbreak happening in a country shows how the government is taking their role seriously in serving the citizens legal certainty and the assurance on the realization of political campaigns held by the government before they gained trust from their citizens and got elected into the government branches. Immediate serious actions in responding the country's outbreak have proven to strengthen the trust of a good governance application from the citizens, which shows how serious their government is taking their integrated and professional role as a country's authorized leaders.

South Korean government has also been conducting many other strategies along with extensive screening explained above. Those strategies are drive through (drive-thru) screening, mobilization online tracking with immediate warnings, developing a questionnaire application, and supplying protective gears for the public sectors (as well as distributing them). By determining patient's mobilizations, the government could imperatively prevent further transmissions. They used Global Positioning System (GPS) records which tracked down from their cellular or credit devices to generate a movement pattern which will be analysed as the mobilization map control (H. Ko, Leitner, Kim, \& Jeong, 2017). In handling Covid-19 like those, South Korea doesn't need any emergency law, but they just use legislative scrutiny and judicial oversight with more responsive action in Infectious Disease Control and Prevention Act (ISDPA) (Lee \& Kim, 2021). 
Not only using the GPS records from their people's mobile devices, the government also traces the mobilization through CCTVs and credit card transactions (Hopkins Tanne et al., 2020). Moreover, South Korean government's intensive use of the artificial intelligence (which is known as $\mathrm{AI}$ ) and massive data analytic strategy to track down the possible infected people mobilization who were in contact with an infected patient has given a big influence of their success in handling COVID-19 outbreaks (Balilla, 2020). Hence, the government never regulated regions in South Korea into strict lockdown. Those strategies mentioned previously were preceptive clever strategies implied by the government of South Korea, but they need a perfect strategy to wrap up the government acts mentioned before into a big key success in handling a governance problem of COVID-19 outbreak faced by South Korea. That big key success is no other than problem and reports transparency given to the citizens by South Korean government.

Not just the government's success in handling the COVID-19 pandemic expansion, the citizens of South Korea have also followed the regulations instructed by their government and cooperated with the smart strategies used seriously. Which then the harmonization of the government acts and the citizen cooperation will result a great teamwork between the government and their citizens in accomplishing the government's goal in flattening the curve of COVID-19 transmission.

\section{The Accuracy and Effectiveness of Indonesian Government Acts Regulated in Handling COVID-19 in Indonesia}

The COVID-19 outbreak first came into Indonesia in the end of February. In early March, President Joko Widodo declared that there were 2 (two) citizens in Depok were infected by the coronavirus which later then increased rapidly into the number of 1,528 confirmed positive cases that caused the death of 136 patients and it has alarmed the Republic of Indonesia ever since. The internal communication conducted by Jokowi's political cabinet has gathered public interest on the government act confusions regulated by the government in executive branch (Setiati \& MK Azwar, 2020). These government act confusions were shown on how the Indonesian government was very laid back on the early stage of COVID-19 outbreak.

The nation's Case Fatality Rate (CFR) in Indonesia was really high by that early stage, which hit the $8.9 \%$ of CFR then decreased down into 6.93\% in mid-May. But apparently the COVID-19 transmission curve in Indonesia ironically keeps raising up by June 112020 which the confirmed positive cases informed on Gugus Tugas Percepatan Penanganan COVID-19 (Task Force to Accelerate the Handling of COVID-19) of Indonesia's website hit the total number of 34,316 confirmed cases with 1,241 new confirmed cases, 20,228 patients are currently isolated, 12,129 patients have recovered and released from isolation, and 1,959 deceased related to COVID-19. These numbers are embarrassingly much higher compared to South Korea's cases. The most recent updates on COVID-19 confirmed cases in Indonesia is shown in Chart 1 below. 


\section{Chart 1. Daily COVID-19 Cases in Indonesia (combined graphics)}

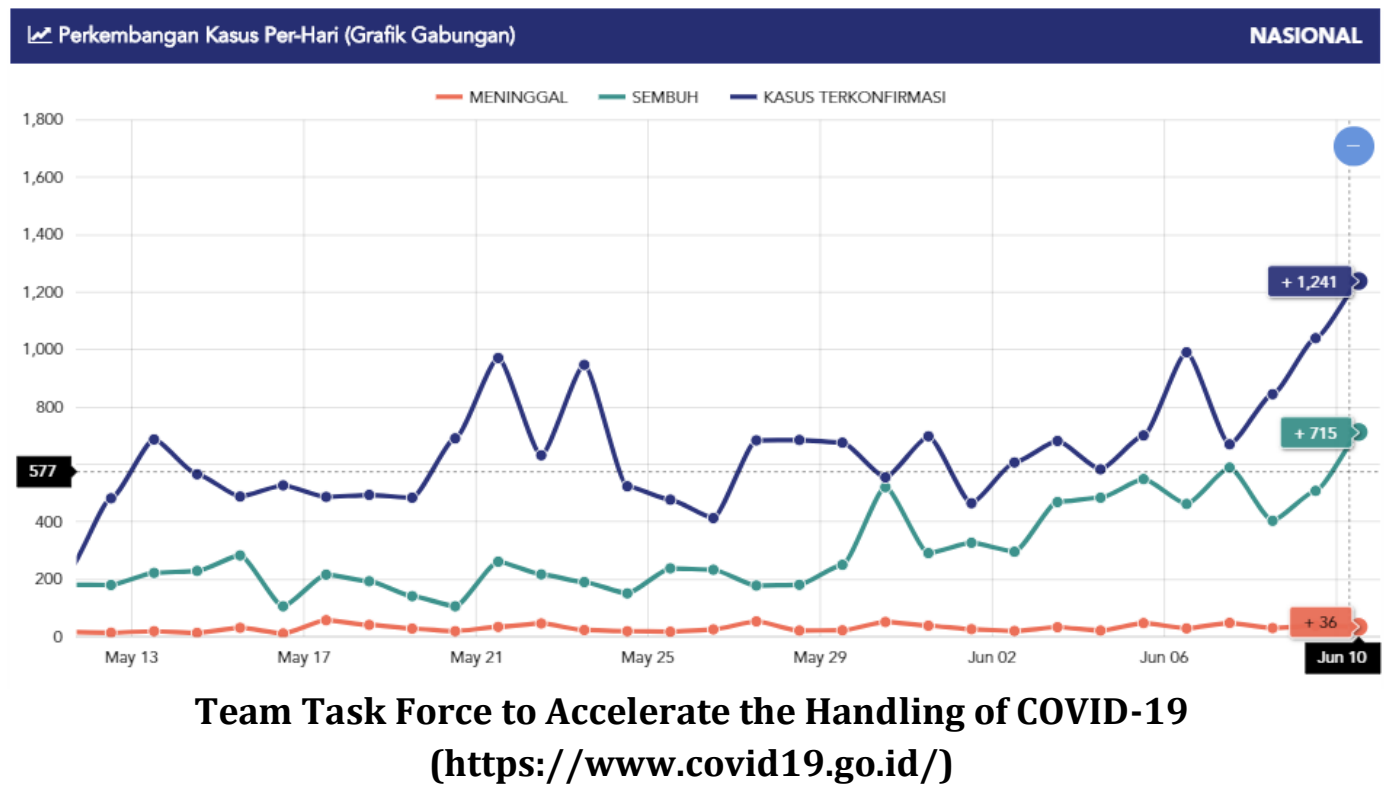

From the data given on the chart above, we can see the COVID-19 outbreak in Indonesia is until now. In South Korea, as on June 11 2020, there are 11,947 confirmed cases (with 47 new cases), people who have released from isolation with a number of 10,654 , while patients who are currently being isolated as much as 1,017 (2 new patients), with 276 deceased (there is no new death case). This update of COVID-19 cases can be accessed on South Korean Ministry of Health and Welfare's website.

Before a positive case was found and confirmed, a number of countries had suspected that Indonesia was not infected from the spread of COVID-19. Indonesia is considered not being capable of carrying out accurate testing strategy, as well as not having and adequate health system, which the government has been suspected of covering up the factual conditions that the government is currently facing from the public (Martha, 2020). This is damaging the trust of the citizen in which damaging the image of Indonesia itself. In addition, unprepared health services and major government acts taken need to be reviewed and changed to eradicate this humiliating infection (Setiati \& MK Azwar, 2020). The Indonesian government is urged to tighten the calls of the Stay At Home campaign (Amiruddin, 2020) for its citizens, as well as regulating sanctions to those who violate this regulation, reduce the expansion of coronavirus with a large-scale regional quarantine, improve the medical facilities, and increase the availability of Personal Protective Equipment (APD).

Economic, medical, and education sectors are three main sectors severed most harms due to COVID-19 pandemic. Indonesian economy is projected to enter a recession followed by millions of people are becoming poor the longer this pandemic appears in Indonesia, until today. In the economic sector itself, not only COVID-19 pandemic has severely affected the food market in the rising prices of commodities, it is also impacting the economy of Indonesia in some other sectors such as petroleum price, value chain, as well as travel and tourism sector. 
Countries in Southeast Asia have decided to lend money from international institutions to overcome the harmful impacts of COVID-19, including Indonesia. Following the recession of Indonesian economy, the unemployment number in Indonesia during this pandemic has recorded reaching up to nine million which stated by Sri Mulyani as Indonesian Minister of Finance (Muzakki, 2020). Referring to such conditions, the number is predicted to keep rising since the Government of Indonesia has officially extended the Work From Home regulations remembering that a lot of business sectors are closed nowadays.

In medical sector, how Indonesian government acts concerning health system have carried out so far. Self-quarantine is not enough if it is not accompanied by the ability to detect potential suspect cases followed by the confirmed cases isolation (World Health Organization). Moreover, there are cases found with mild-symptomatic or asymptomatic (J.H. Ko et al., 2020). The more concerning issue is that infected suspects are found to not have any symptom at all recently, which make us hard to detect and isolate them immediately. Although Indonesian government has called for the citizens to stay at home or wear masks it is necessary for them to go out in public, the people themselves tend to not obey the government advices. It is because there is no formal regulation governing that procedure. At the end of the day, it only becomes an informal safety guide concerning public health during COVID-19 pandemic in Indonesia.

The education sector as the most controversial sector following the uncertainty of government regulations on the learning system used during this pandemic. In this matter, the regulations about how the learning system will be proceed during COVID-19 pandemic are regulated under Minister of Education and Culture Handbill Number 4 of 2020 concerning The Implementation of Education Policies in The Emergency Period of COVID19 Spread. The most prominent impact is stated on point number one which regulates that the national exams (UN) are cancelled, as well as the expertise competency test for vocational high school. Not only the elementary school, middle school, high school, and vocational high school which education systems are impacted, the education system in higher education institutions in university level is also impacted by this COVID-19 pandemic. The annual internship and Community Service Program (KKN) are cancelled due to COVID-19 pandemic, some programs are done through online platforms. Meanwhile, the learning process is changed into some online platforms such Zoom Meeting, G-Meet, Edmodo, Google Classroom, and webinars (Ratu, Khasanah, Pramudibyanto, \& Widuroyekti, 2020).

Moreover, in the education sector, The Indonesian Children Protection Commission (KPAI) has urged the governments to evaluate the home-study e-learning system (MBN Wajdi, I Kuswandi, \& U Al Faruq, 2020). KPAI Commissioner of Education, Retno Listyarti claimed that this e-learning system is ineffective with the argument of most teachers most likely give overload assignments every day in the concept of misinterpretation towards the e-learning system itself. She stated that KPAI has received many complaints from parents that this wrong method applied by teachers has caused stress to their children. We cannot deny the fact that COVID-19 is impacting "Merdeka Belajar" (freedom in learning) concept proposed by the Minister of Education, Nadiem Makarim, which includes National Standard of School Examination (UASBN), National Examination (UN), Learning Plan Sheet (RPP), and New Students Admission Zoning-based Regulation (PPDB) (A Abidah \& HN Hidaayatullaah, 2020). There will always be advantages and disadvantages in a policy-making. 
The most severe impact in education sector due to COVID-19 pandemic felt by elementary school students who cannot study and play freely in school (Tabi'in, 2020). Students who are still in their childhood period tends to have the needs to socialize with their friends in person the most, in order to develop their imaginary and creative thinking skill. But even though that need is currently not able to fulfil, the e-learning seems to works just fine (WAF Dewi, 2020). This is due to the application of "blended learning", where two study methods of conventional method and e-learning are combined. This has made students to feel comfortable and creative during the new adaptation of learning process.

\section{Policy Reconstructions Should be Adapted by The Government of Indonesia from South Korean Government}

The government of Indonesia has established some Government Regulations, including the Minister of Health Regulations. As for several Government Regulations that must be formed, namely Procedures for Determination and Revocation of Public Health Emergency, Public Health Emergency Management, Procedures for Implementing Regional Quarantine at the Entrance, Procedures for Imposing Administrative Sanctions on Skippers, Captain Pilots, and Drivers (related to Health Quarantine Documents and the Criteria and Implementation of Home Quarantines), Regional Quarantines, Hospital Quarantines, and Large-Scale Social Restrictions (Telaumbanua, 2020). Therefore, regulating those regulations in a form of Law is considered as a first urgent step to prevent the spread of COVID-19.

In the sake of medical facilities, Indonesia needs to considerate the implementation of massive RT-PCR testing program (Sucahya, 2020) conducted by South Korean government in order to rapidly decrease new confirmed cases that keeps rising high each day. In May, the Executive Director of a South Korean company named Korea Tomorrow \& Global, Kwon Min Suk, has donated RT-PCR test kits for Indonesia which worth IDR 1.2 billion. Not just Korea Tomorrow and Global, some other Korean companies have also donated tens of thousands rapid test kits for Indonesia, which more than 100,000 RT-PCR test kits have been donated. Those companies are Korea Aerospace Industries (KAI), Daewoo Shipbuilding \& Marine Engineering, Posco, and LG. Apparently, the government of South Korea also donated 32,200 RT-PCR test kits to the government of Indonesia in April 2020 (Liputan 6 News).

Indonesia is now currently applying the concept of New Normal (PRAGHOLAPATI, 2020). New Normal is one of the government's attempts to handle the stability of Indonesian economy after approximately 4 (four) months after since the first case of COVID19 confirmed in Indonesia, with the fact that Indonesian CFR graphic has not yet flatten. The concept of New Normal is that the government wants to mitigate the optimization of workplace readiness to go back to normal (just like how the current condition in South Korea is). This strategy is expected to lower the impact of COVID-19 pandemic on the citizen's wealth gradually. Business, profession, and other employment sectors are expected to operate regularly like before. But during this New Normal condition, the government urges the people to obey the health protocol seriously. Everyone must wear a mask, apply the safety distance in both public transportations and workplaces, also that hand sanitizers need to be provided at workplaces. These protocols are regulated under the Decree of the Indonesian Minister of Health Number HK.01/MENKES/328/2020 concerning Guidelines 
for Preventing and Controlling COVID-19 at the Office and Industry Workplaces in Supporting Business Continuity during Pandemic Situation.

Despite the Indonesian government's confidence in implementing the New Normal era, people are still haunted with the fact that Indonesian CFR still demands high. For example, how Jakarta-Bogor-Depok-Tangerang-Bekasi (Jabodetabek) and Surabaya have become black zones due to thousands of COVID-19 confirmed cases. People are concerned that the spread of COVID-19 will be extremely overspread due to this new government regulation. The government has not yet set any legal sanctions following the new given protocols. Social responsibility also plays an important role in flattening the CFR curve. Dana Riksa Buana in her research article found that Indonesian citizens who do not obey the government advices tend to have cognitive bias, where they feel like they know or understand the pandemic condition better than the government does on the basis of their own perceptions (Riksa Buana, 2020).

Aside from New Normal regulation, related to self-quarantine policy, or more known as lockdown, actually has been regulated under Law Number 6 of 2018 concerning Health Quarantine. This has been realized to the application of Large-Scaled Social Restrictions (PSBB) under the Government Regulation Number 21 of 2020 concerning Large-Scaled Social Restrictions in Accelerating the Handling of COVID-19, and the protocol guidelines are regulated under the Minister of Health Regulation Number 9 of 2020 concerning The Guidelines of The Government Regulation Number 21 of 2020. Meanwhile, this regulation is considered ineffective due to people disobedience towards the regulations that have been issued. In Jakarta itself, citizens are mobilizing from inside and out of Jakarta, reinforcing the presumption that millions of residents are going back to their hometowns due to the fear of pandemic or losing their job (Thorik, 2020).

The government apparently issued the policy of freeing thousands public prisoners (not interfered with corruptor prisoners) under the Minister of Justice and Human Rights Regulation Number 10 of 2020 concerning Conditions for The Provision of Assimilation and Integration Rights for Prisoners and Juveniles in the Context of Preventing and Overcoming COVID-19 Spread. This policy was taken through careful consideration of the opportunity to spread among fellow prisoners easily due to the conditions of the crowded, narrow, and very improper prison cells (NR Yunus, 2020). However, the policy has caused disquiet within the community. After since this policy issued, a lot of minor crimes have happened (such as theft).

The people's response to a government act also plays an important role in the actualization of the regulation itself (Rizal Ardy Hariandy Hamid, 2020). On the other hand, in the mirror of South Korean government's success in flattening their CFR curve, the role of their citizens on obeying the government regulations issued also played as a key factor. It cannot be denied that trade-off might be needed if the government wants to do both flattening the curve and maintaining economic growth (Apresian, 2020). To flatten the curve, some businesses need to shut down to hamper the spread of coronavirus. In the other hand, Indonesia's citizen needs to be ready to face the rise of CFR curve if we want to maintain the economic growth by allowing usual daily activities to happen like normal. In this case, Indonesian government has done the first method, although it was not effective in flattening the curve yet the number of confirmed cases keeps increasing rapidly (around 
1000 new cases per day). And now, the government plans to actualize the second method, which then known as New Normal era.

It is good to know that the government is planning to adapt some of the smart strategy done by countries who have successfully tackled down the outbreaks, such as South Korea. South Korea is not facing any other new confirmed case for a stable period of time, which made this "new normal" concept works just fine in their country. Not just working perfectly well, the concept of bringing things back to normal has effectively maintained the economic growth in South Korea. While in Indonesia, it is no more secret that the number keeps increasing in an extreme augment to approximately 1,000 new confirmed cases per day. Without the obedience of the people, serious legal sanctions, as well as good preparations and protocols, this pandemic period will not end anytime soon.

The Government of Indonesia is urged to legalize policies concerning sanctions for those who do not cooperate with the government regulations as instructed. This is necessary and urgent because it will play a key role in eradicating this COVID-19 pandemic, as well as flattening the curve. Other than that, rapid testing still needs to applied continuously (Djalante, Lassa, Setiamarga, \& Mahfud, 2020). Therefore, Indonesia need to do the massive detection tests broadly as soon as possible and focusing on that first, along with realizing New Normal concept to heal the economic condition in Indonesia. Before that, Indonesia need to map the possibly infected people to the right medical handling.

Therefore, the harmony between the government on issuing regulations concerning COVID-19 pandemic and the responsibility of citizen participation on obeying the government's protocols plays a vital role in combating current pandemic situation. Hence the meaning of social responsibility itself is an ethical framework of people contribution within their own community welfare. A simple modelling simulation following the early pandemic phase data in Indonesia was conducted and resulted that the strategy to handle the pandemic in Indonesia implemented by Indonesian government is as effective as in South Korea (Nuraini, Khairudin, \& M Apri, 2020). The simulation was conducted using Richard's Curve following the parameter values used by South Korean government.

\section{CONLCUSION}

Clever strategies implied by South Korean government in handling COVID-19 outbreaks are data transparency and massive well-organized rapid testing program. While, the accuracy and effectiveness of Indonesian government acts regulated in handling covid19 in Indonesia only revolves around policies that are less relevant, such as work from home, release of prisoners, or new normal era. Policy reconstructions should be adapted by the government of Indonesia from South Korean government. The harmony between effective regulations implemented by South Korean government and its people's social responsibility should be taken seriously as an example to adapt by both Indonesian government and Indonesian citizens.

\section{REFERENCES}

A Abidah, \& HN Hidaayatullaah. (2020). The Impact of Covid-19 to Indonesian Education and Its Relation to the Philosophy of "Merdeka Belajar." Studies in Philosophy of Science and Education (SiPoSE), 1(1), 40. Retrieved from 
https://scie-journal.com/index.php/SiPoSE/article/view/9

Abdillah, L. A. (2020). Stigma Terhadap Orang Positif COVID-19. In Pandemik COVID19: Antara Persoalan dan Refleksi di Indonesia (pp. 11-24). Medan: Yayasan Kita Menulis.

Al-Fatih, S., Ahsany, F., \& Alamsyah, A. F. (2020). Legal Protection of Labor Rights During the Coronavirus Disease 2019 (Covid-19) Pandemic. Jurnal Pembaharuan Hukum, 7(2), 100-115. https://doi.org/10.26532/jph.v7i2.10975

Amiruddin, R. (2020). Evaluasi Gerakan "Di Rumah Saja": Karantina dan Pembenahan Serius. Retrieved October 26, 2020, from Detik News website: https://news.detik.com/kolom/d-4958188/evaluasi-gerakan-di-rumah-sajakarantina-dan-pembenahan-serius

Apresian, S. R. (2020). Responding to the COVID-19 Outbreak in Indonesia: Lessons from European Countries and South Korea. Jurnal Ilmiah Hubungan Internasional, Special Edition, 3.

Balilla, J. (2020). Assessment of COVID-19 Mass Testing: The Case of South Korea Redundancy Reduction Using Correlation Based Method View project Assessment of COVID-19 Mass Testing: The Case of South Korea. SSRN Electronic Journal, Special Edition. https://doi.org/10.2139/ssrn.3556346

Cohen, J., \& Kupferschmidt, K. (2020). Countries test tactics in 'war'against COVID-19. The American Association for the Advancement of Science, 367(6484), 1287. Retrieved https://science.sciencemag.org/content/367/6484/1287.summary

Coronavirus Disease-19(COVID-19), Republic of Korea. (2020). Retrieved July 1, 2020, from http://ncov.mohw.go.kr/en/

Djalante, R., Lassa, J., Setiamarga, D., \& Mahfud, C. (2020). Review and analysis of current responses to COVID-19 in Indonesia: Period of January to March 2020. Elsevier: Progress in Disaster Science, Special 6th Edition, 2. Retrieved from https://www.sciencedirect.com/science/article/pii/S2590061720300284

Her, M. (2020). How Is COVID-19 Affecting South Korea? What Is Our Current Strategy? Disaster Med Public Health Prep, 1(1), 1-3. https://doi.org/10.1017/dmp.2020.69

Hopkins Tanne, J., Hayasaki, E., Zastrow, M., Pulla, P., Smith, P., \& Garcia Rada, A. (2020). Covid-19: How Doctors and Healthcare Systems are Tackling Coronavirus Worldwide. The British Medical Journal, 1(1), 2. https://doi.org/10.1136/bmj.m1090

Ko, H., Leitner, J., Kim, E., \& Jeong, J. (2017). Structure and enforcement of data privacy law in South Korea. International Data Privacy Law, 7(2), 100-114. https://doi.org/10.1093/idpl/ipx004

Ko, J.-H., Joo, E.-J., Park, S.-J., Baek, J. Y., Kim, W. D., Jee, J., ... Peck, K. R. (2020). Neutralizing Antibody Production in Asymptomatic and Mild COVID-19 Patients, in Comparison with Pneumonic COVID-19 Patients. Journal of Clinical Medicine, 9(7), 2268. https://doi.org/10.3390/jcm9072268

Lee, S., \& Kim, T.-H. (2021). South Korea's Combating COVID-19 Under the Rule of Law. Retrieved May 27, 2021, from Verfassungsblog website: https://verfassungsblog.de/south-koreas-combating-covid-19-under-the-ruleof-law/

Martha, J. (2020). Pemanfaatan Diplomasi Publik oleh Indonesia dalam Krisis Covid19. Jurnal Ilmiah Hubungan Internasional, Special Edition, 4. https://doi.org/10.1002/9781118516812.ch12 
MBN Wajdi, I Kuswandi, \& U Al Faruq. (2020). Education Policy Overcome Coronavirus, A Study of Indonesians. EDUTEC: Journal of Education and Technology, 3(2), 102. Retrieved from http://ejournal.ijshs.org/index.php/edu/article/download/42/31

Muzakki, F. (2020). The Global Political Economy Impact of Covid-19 and The Implication to Indonesia. Journal of Social Political Sciences, 1(2), 78. Retrieved from http://e-journal.unas.ac.id/index.php/jsps/article/view/11

NR Yunus. (2020). Kebijakan Covid-19, Bebaskan Narapidana dan Pidanakan Pelanggar PSBB. 'ADALAH: Buletin Hukum Dan Keadilan, 4(1), 119. Retrieved from http://journal.uinjkt.ac.id/index.php/adalah/article/view/15262

Nuraini, N., Khairudin, K., \& M Apri. (2020). Modeling Simulation of COVID-19 in Indonesia based on Early Endemic Data. Commun Biomath Sci, 3(1), 7. Retrieved from http://journals.itb.ac.id/index.php/cbms/article/view/13395

Peter Mahmud Marzuki. (2014). Penelitian Hukum. Jakarta: Kencana Prenada Media Group.

PRAGHOLAPATI, A. (2020). NEW NORMAL“INDONESIA"AFTER COVID-19 PANDEMIC. Bandung.

Pratama, N. A., \& Hidayat, D. (2020). Pengetahuan dan Perilaku Masyarakat Memaknai Social Distancing. Jurnal Digital Media \& Relationship, 2(1), 1-10.

RA, M. S., Hamdika, Y., \& Al-Fatih, S. (2020). The Impact of COVID-19 Through the Lens of Islamic Law: An Indonesian Case. Lentera Hukum, 7(3), 267-278. https://doi.org/https://doi.org/10.19184/ejlh.v7i3.18983

Ratu, D., Khasanah, A. U., Pramudibyanto, H., \& Widuroyekti, B. (2020). Pendidikan dalam Masa Pandemi Covid-19. Jurnal Sinestesia, 10(1), 46. Retrieved from https://sinestesia.pustaka.my.id/journal/article/view/44

RD Azmi, \& RHS Aji. (2020). Kebangkitan Nasional: Pemuda Melawan Pandemi Global. 'ADALAH: Buletin Hukum Dan Keadilan, 4(1), 85. https://doi.org/10.15408/adalah.v4i1.15761

Riksa Buana, D. (2020). Analisis Perilaku Masyarakat Indonesia dalam Menghadapi Pandemi Virus Corona (Covid-19) dan Kiat Menjaga Kesejahteraan Jiwa. Jurnal Sosial Dan Budaya Syar-I, 7(3), 221. https://doi.org/10.15408/sjsbs.v7i3.15082

Rizal Ardy Hariandy Hamid, A. (2020). Social responsibility of medical journal: a concern for COVID-19 pandemic. Medical Journal of Indonesia, 29(1), 2. https://doi.org/10.13181/mji.ed.204629

Setiati, S., \& MK Azwar. (2020). COVID-19 and Indonesia. Acta Medica Indonesiana, 52(1), $85 . \quad$ Retrieved from https://www.researchgate.net/profile/Muhammad_Azwar3/publication/34064 5813_COVID-19_and_Indonesia/links/5e96ba6a92851c2f52a2ef2e/COVID-19and-Indonesia.pdf

Sucahya, P. K. (2020). Barriers to Covid-19 RT-PCR Testing in Indonesia: A Health Policy Perspective. Journal of Indonesian Health Policy and Administration, 5(2), 36-42. https://doi.org/10.7454/ihpa.v5i2.3888

Tabi'in, A. (2020). Problematika Stay At Home Pada Anak Usia Dini Di Tengah Pandemi Covid 19. Jurnal Golden Age, 04(1), 190-200.

Telaumbanua, D. (2020). Urgensi Pembentukan Aturan Terkait Pencegahan Covid-19 di Indonesia. QALAMUNA: Jurnal Pendidikan, Sosial Dan Agama, 12(1), 59-70. Retrieved from https://ejournal.insuriponorogo.ac.id/index.php/qalamuna/article/view/290 
Thorik, S. H. (2020). Efektivitas Pembatasan Sosial Berskala Besar Di Indonesia Dalam Penanggulangan Pandemi Covid-19. 'ADALAH: Buletin Hukum Dan Keadilan, 4(1), 115. https://doi.org/10.15408/adalah.v4i1.15506

Valerisha, A., \& Putra, M. A. (2020). Pandemi Global COVID-19 dan Problematika Negara-Bangsa: Transparansi Data Sebagai Vaksin Socio-digital? Jurnal Ilmiah Hubungan Internasional, Special Edition, 5. Retrieved from http://103.36.68.33/index.php/JurnalIlmiahHubunganInternasiona/article/do wnload/3871/2913

WAF Dewi. (2020). Dampak Covid-19 terhadap implementasi pembelajaran daring di Sekolah Dasar. Edukatif: Jurnal Ilmu Pendidikan, 2(1), 58. Retrieved from https://edukatif.org/index.php/edukatif/article/view/89

Worldometer. (2020). Retrieved July 1, 2020, from https://www.worldometers.info/coronavirus/country/us/

\section{ACKNOWLEDGEMENT}

None. Thanks. 